\title{
Author Correction: Labile organic carbon pools and enzyme activities of Pinus massoniana plantation soil as affected by understory vegetation removal and thinning
}

Yafei Shen ${ }^{1}$, Ruimei Cheng ${ }^{1,2}$, Wenfa Xiao ${ }^{1,2}$, Shao Yang ${ }^{1}$, Yan Guo ${ }^{1}$, Na Wang ${ }^{1}$, Lixiong Zeng ${ }^{1,2}$, Lei Lei $^{1,2}$ \& Xiaorong Wang ${ }^{1}$

Correction to: Scientific Reports https://doi.org/10.1038/s41598-017-18812-x, published online 12 January 2018

The Article contains errors in Table 1. The correct Table 1 appears below.

This Article contains errors in the labelling and scaling of the charts in Figure 1. The correct Figure 1 appears below:

In addition, the Article also contains errors in the units and labelling for the charts in Figure 2. The correct Figure 2 appears below:

The Article also contains errors in Table 2 where EOC was incorrectly given as ROC. In addition, Table 2 contains a typographical error in the fourth row of the 'Invertase' column where ' + ' is erroneously present.

This Article contains errors in the Materials and Methods section under subheading 'Soil analysis'.

"This subsample was used to determine $\mathrm{NH}_{4}{ }^{+}-\mathrm{N}, \mathrm{NO}_{3}{ }^{-}-\mathrm{N}, \mathrm{DOC}, \mathrm{MBC}, \mathrm{EOC}$, and enzyme activities (cellulase, amylase, invertase, and catalase). The other subsample was air-dried and sieved before use for the analysis of SOC and other soil properties (TN, TP, TK, AK, AP, and pH)."

should read:

"This subsample was used to determine DOC, MBC, EOC, and enzyme activities (cellulase, amylase, invertase, and catalase). The other subsample was air-dried and sieved before use for the analysis of SOC and other soil properties (TN, $\mathrm{NH}_{4}{ }^{+}-\mathrm{N}, \mathrm{NO}_{3}{ }^{-}-\mathrm{N}, \mathrm{TP}, \mathrm{TK}, \mathrm{AK}, \mathrm{AP}$, and $\left.\mathrm{pH}\right)$."

Also under the subheading 'Sample analyses'.

"Soil $\mathrm{pH}$ was determined from a soil water $(1: 5 \mathrm{w} / \mathrm{v})$ suspension, prepared by shaking $30 \mathrm{~min}$, using a conductivity meter."

should read:

"Soil pH was determined from a soil water (1:2.5) suspension, prepared by shaking $30 \mathrm{~min}$, using a conductivity meter."

${ }^{1}$ Key Laboratory of Forest Ecology and Environment, State Forestry Administration, Research Institute of Forest Ecology, Environment and Protection, Chinese Academy of Forestry, Beijing, 100091, China. ${ }^{2}$ Co-innovation Center for Sustainable Forestry in Southern China, Nanjing Forestry University, Nanjing, 210037, China. Correspondence and requests for materials should be addressed to R.C. (email: cafcheng@sina.com) 


\begin{tabular}{|c|c|c|c|c|c|c|c|c|c|}
\hline $\begin{array}{l}\text { Treat- } \\
\text { ments }\end{array}$ & $\begin{array}{l}\text { Soil depth } \\
\text { (cm) }\end{array}$ & Soil pH & $\begin{array}{l}\text { TN } \\
\left(\mathrm{g} \mathrm{kg}^{-1}\right)\end{array}$ & $\begin{array}{l}\text { TP } \\
\left(\mathrm{g} \mathrm{kg}^{-1}\right)\end{array}$ & $\begin{array}{l}\text { TK } \\
\left(\mathrm{g} \mathrm{kg}^{-1}\right)\end{array}$ & $\begin{array}{l}\text { AP } \\
\left(\mathrm{mg} \mathrm{kg}^{-1}\right)\end{array}$ & $\begin{array}{l}\mathrm{AK} \\
\left(\mathrm{mg} \mathrm{kg}^{-1}\right)\end{array}$ & $\begin{array}{l}\mathrm{NO}_{3}{ }^{-}-\mathrm{N} \\
\left(\mathrm{mg} \mathrm{kg}^{-1}\right)\end{array}$ & $\begin{array}{l}\mathrm{NH}_{4}^{+}-\mathrm{N} \\
\left(\mathrm{mg} \mathrm{kg}^{-1}\right)\end{array}$ \\
\hline \multirow{3}{*}{$\mathrm{CK}$} & $0-10$ & $5.85 \pm 0.02 \mathrm{Aa}$ & $1.65 \pm 0.01 \mathrm{Aa}$ & $0.21 \pm 0.01 \mathrm{Aa}$ & $17.05 \pm 0.12 \mathrm{Aa}$ & $0.84 \pm 0.10 \mathrm{a}$ & $184.68 \pm 2.19 \mathrm{Aa}$ & $17.79 \pm 0.89 \mathrm{Aa}$ & $43.00 \pm 3.51 \mathrm{Aa}$ \\
\hline & $10-20$ & $5.92 \pm 0.06 \mathrm{Ba}$ & $1.15 \pm 0.01 \mathrm{Ba}$ & $0.18 \pm 0.01 \mathrm{Ba}$ & $16.76 \pm 0.13 \mathrm{Ba}$ & $0.99 \pm 0.17 \mathrm{a}$ & $145.83 \pm 2.80 \mathrm{Ba}$ & $11.26 \pm 0.99 \mathrm{Ba}$ & $37.34 \pm 3.48 \mathrm{Ba}$ \\
\hline & $20-30$ & $6.07 \pm 0.05 \mathrm{Ca}$ & $0.97 \pm 0.01 \mathrm{Ca}$ & $0.17 \pm 0.01 \mathrm{Ba}$ & $17.13 \pm 0.10 \mathrm{Aa}$ & $0.98 \pm 0.17 \mathrm{a}$ & $136.58 \pm 0.47 \mathrm{Ca}$ & $5.40 \pm 0.0 .37 \mathrm{Ca}$ & $24.66 \pm 0.56 \mathrm{Ca}$ \\
\hline \multirow{3}{*}{ SC } & $0-10$ & $6.02 \pm 0.05 \mathrm{Aa}$ & $1.57 \pm 0.02 \mathrm{Ab}$ & $0.20 \pm 0.01 \mathrm{Aa}$ & $18.21 \pm 0.15 \mathrm{Ab}$ & $1.23 \pm 0.17 \mathrm{Aa}$ & $146.45 \pm 2.04 \mathrm{Ab}$ & $11.65 \pm 0.22 \mathrm{Ab}$ & $45.66 \pm 0.69 \mathrm{Aa}$ \\
\hline & $10-20$ & $6.16 \pm 0.03 \mathrm{Ba}$ & $1.16 \pm 0.01 \mathrm{Ba}$ & $0.19 \pm 0.01 \mathrm{Ba}$ & $18.08 \pm 0.25 \mathrm{Bb}$ & $2.35 \pm 0.29 \mathrm{Bb}$ & $126.18 \pm 1.28 \mathrm{Bb}$ & $4.48 \pm 0.14 \mathrm{Bb}$ & $18.96 \pm 0.23 \mathrm{Bb}$ \\
\hline & $20-30$ & $6.33 \pm 0.03 \mathrm{Ca}$ & $0.90 \pm 0.01 \mathrm{Cb}$ & $0.18 \pm 0.01 \mathrm{Ca}$ & $19.52 \pm 0.19 \mathrm{Cab}$ & $1.57 \pm 0.4 \mathrm{ABab}$ & $110.43 \pm 2.47 \mathrm{Cb}$ & $2.75 \pm 0.34 \mathrm{Cb}$ & $12.76 \pm 1.28 \mathrm{Cb}$ \\
\hline \multirow{3}{*}{ LIT } & $0-10$ & $6.17 \pm 0.02 \mathrm{Aa}$ & $1.37 \pm 0.04 \mathrm{Ac}$ & $0.19 \pm 0.01 \mathrm{Aa}$ & $16.54 \pm 0.21 \mathrm{Ac}$ & $2.11 \pm 0.39 \mathrm{~b}$ & $140.60 \pm 3.29 \mathrm{Acb}$ & $9.73 \pm 0.42 \mathrm{~A} \mathrm{c}$ & $50.69 \pm 2.91 \mathrm{Ab}$ \\
\hline & $10-20$ & $6.25 \pm 0.03 \mathrm{Ba}$ & $1.04 \pm 0.02 \mathrm{Bb}$ & $0.17 \pm 0.01 \mathrm{Ba}$ & $17.14 \pm 0.08 \mathrm{Aa}$ & $1.46 \pm 0.92 \mathrm{ac}$ & $127.40 \pm 2.50 \mathrm{Bb}$ & $2.57 \pm 0.10 \mathrm{Bc}$ & $14.79 \pm 0.47 \mathrm{Bc}$ \\
\hline & $20-30$ & $6.48 \pm 0.02 \mathrm{Ca}$ & $0.85 \pm 0.01 \mathrm{Cc}$ & $0.17 \pm 0.01 \mathrm{Ba}$ & $17.70 \pm 0.24 \mathrm{Aab}$ & $2.51 \pm 0.61 \mathrm{~b}$ & $126.25 \pm 3.29 \mathrm{Aa}$ & $2.45 \pm 0.13 \mathrm{Bb}$ & $10.99 \pm 0.28 \mathrm{Cb}$ \\
\hline \multirow{3}{*}{ HIT } & $0-10$ & $5.97 \pm 0.05 \mathrm{Aa}$ & $1.49 \pm 0.01 \mathrm{Ad}$ & $0.19 \pm 0.01 \mathrm{Aa}$ & $16.43 \pm 0.16 \mathrm{Acd}$ & $0.82 \pm 0.70 \mathrm{Aa}$ & $130.78 \pm 0.52 \mathrm{Ac}$ & $5.35 \pm 0.19 \mathrm{Ad}$ & $35.79 \pm 3.29 \mathrm{Ac}$ \\
\hline & $10-20$ & $6.07 \pm 0.03 \mathrm{Ba}$ & $1.09 \pm 0.02 \mathrm{Bc}$ & $0.17 \pm 0.01 \mathrm{Ba}$ & $15.83 \pm 0.34 \mathrm{Bc}$ & $1.09 \pm 0.10 \mathrm{ABad}$ & $82.90 \pm 1.60 \mathrm{Bc}$ & $4.90 \pm 0.58 \mathrm{ABb}$ & $34.51 \pm 2.41 \mathrm{Aa}$ \\
\hline & $20-30$ & $6.20 \pm 0.04 \mathrm{Ca}$ & $0.96 \pm 0.01 \mathrm{Ca}$ & $0.18 \pm 0.01 \mathrm{Ca}$ & $16.58 \pm 0.05 \mathrm{Cb}$ & $1.91 \pm 0.90 \mathrm{Bab}$ & $71.68 \pm 1.57 \mathrm{Cc}$ & $3.50 \pm 1.56 \mathrm{Bb}$ & $29.25 \pm 1.50 \mathrm{Bc}$ \\
\hline
\end{tabular}

Table 1. Soil chemical properties at three soil depths in the four forest management treatments (mean value \pm standard error; $n=3$ ). Significant differences among different soil layers subjected to the same treatments are identified with A, B, and C $(p<0.05)$. Significant differences among different treatments of the same soil layer are identified with $\mathrm{a}, \mathrm{b}, \mathrm{c}$, and $\mathrm{d}(\mathrm{p}<0.05)$, based on the analysis of variance.
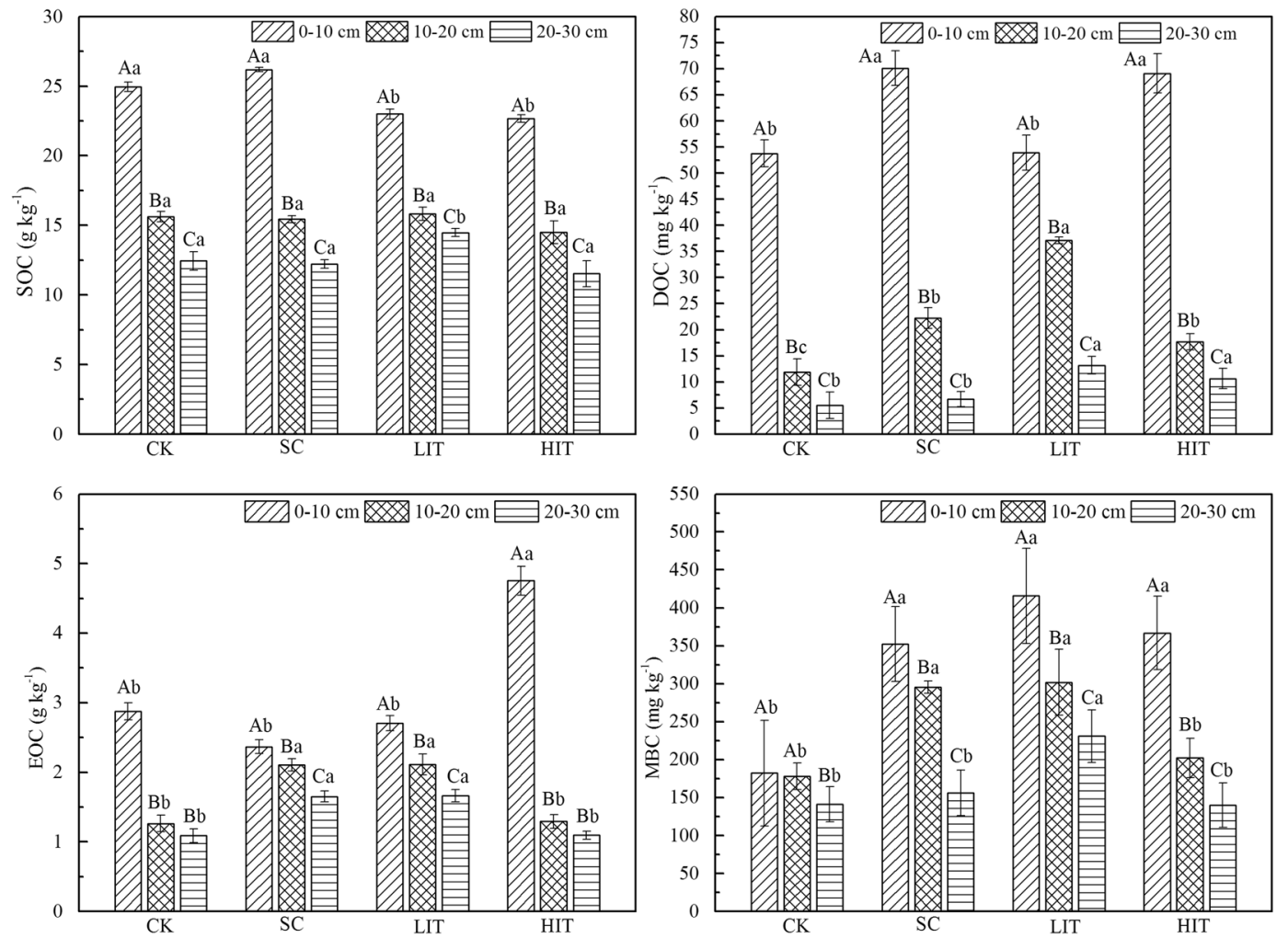

Figure 1. Soil LOC fractions in the four forest management treatments. The three columns in each treatment represent the quantities in soil LOC content at different soil depths. Significant differences among different soil layers subjected to the same treatments are identified with A, B, and C $(\mathrm{p}<0.05)$. Significant differences among different treatments of the same soil layer are identified with $a, b, c$, and $d(p<0.05)$, based on the analysis of variance. Values are means \pm standard error $(n=3)$. 

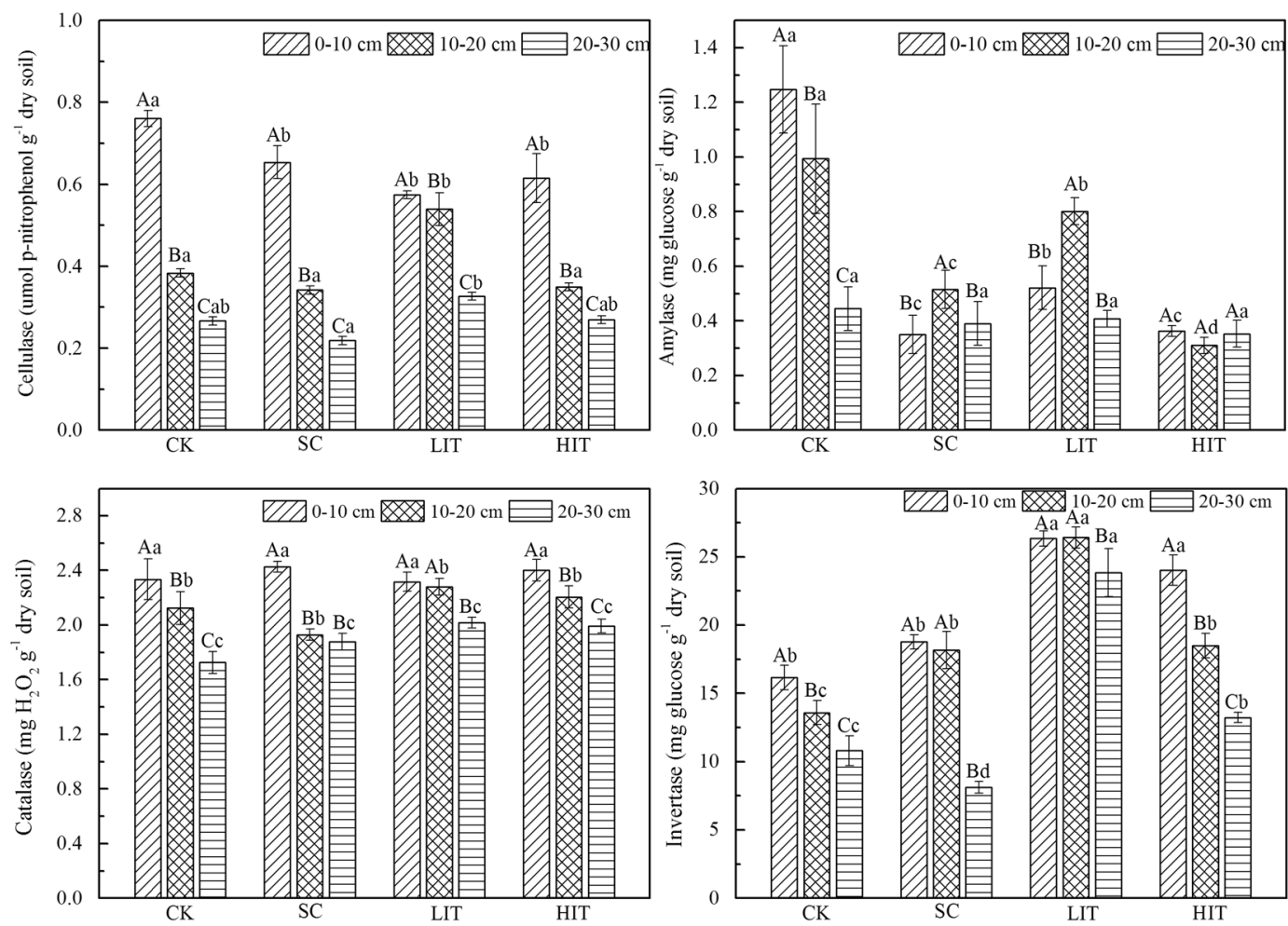

Figure 2. Soil enzymes in the four forest management treatments. The three columns in each treatment represent the quantities of four soil enzymes at different soil depths. Significant differences among different soil layers subjected to the same treatments are identified with $A, B$, and $C(p<0.05)$. Significant differences among different treatments of the same soil layer are identified with $a, b, c$, and $d(p<0.05)$, based on the analysis of variance. Values are means \pm standard error $(n=3)$.

Finally, the authors neglected to cite a previously-published related paper. This is listed below as reference ${ }^{1}$.

As a result, in the Materials and Methods section under subheading 'Soil enzyme activity analysis'

"Soil amylase activity was measured using $2 \mathrm{~g}$ of fresh soil incubated for $24 \mathrm{~h}$ at $37^{\circ} \mathrm{C}$ according to Ebregt's method $^{74}$. Soil invertase activity was measured as at $30^{\circ} \mathrm{C}$ and $\mathrm{pH} 4.65$ in Na-acetate buffer according to Gianfreda's method ${ }^{75}$. Soil cellulase activities were detected by an incubation according to Sharma's $\operatorname{method}^{76}$, and soil catalase activity was determined at $\mathrm{pH}$ 7.0, following the monitoring of the decomposition of $\mathrm{H}_{2} \mathrm{O}_{2}$ at $240 \mathrm{~nm}$ with an extinction coefficient of $43.6 \mathrm{M}^{-1} \mathrm{~cm}^{-1}$ according to Roggenkamp and Sahm ${ }^{77}$."

should read:

"Soil amylase activity was measured using $2 \mathrm{~g}$ of fresh soil incubated for $24 \mathrm{~h}$ at $37^{\circ} \mathrm{C}$ according to methods of Ebregt $^{74}$ and Guan ${ }^{1}$. Soil invertase activity was measured according to Guan's method ${ }^{1}$ and Gianfreda's method $^{75}$. The amylase and invertase activities were expreseed as mg glucose $\mathrm{g}^{-1}$ soil $24 \mathrm{~h}^{-1}$. Soil cellulase activities were detected by an incubation according to Sharma's method ${ }^{76}$ and Guan's method ${ }^{1}$, and the activity was expreseed as $\mu \mathrm{mol} \mathrm{p}$-nitrophenol $\mathrm{g}^{-1}$ soil $^{-1}$. Soil catalase activity was determined at $\mathrm{pH} 7.0$, following the monitoring of the decomposition of $\mathrm{H}_{2} \mathrm{O}_{2}$ at $240 \mathrm{~nm}$ with an extinction coefficient of $43.6 \mathrm{M}^{-1} \mathrm{~cm}^{-1}$ according to Roggenkamp ${ }^{77}$ and $\mathrm{Guan}^{1}$, and the activity was expreseed as $\mathrm{mg} \mathrm{H}_{2} \mathrm{O}_{2} \mathrm{~g}^{-1}$ soil $20 \mathrm{~min}^{-1}$."

\section{Reference}

1. Guan, S. Y. Soil enzymes and their research methods. Agriculture Press. Beijing (1986). 
(c) (i) Open Access This article is licensed under a Creative Commons Attribution 4.0 International License, which permits use, sharing, adaptation, distribution and reproduction in any medium or format, as long as you give appropriate credit to the original author(s) and the source, provide a link to the Creative Commons license, and indicate if changes were made. The images or other third party material in this article are included in the article's Creative Commons license, unless indicated otherwise in a credit line to the material. If material is not included in the article's Creative Commons license and your intended use is not permitted by statutory regulation or exceeds the permitted use, you will need to obtain permission directly from the copyright holder. To view a copy of this license, visit http://creativecommons.org/licenses/by/4.0/.

(c) The Author(s) 2018 